\title{
OBITUARY
}

\section{ARTHUR EDWARD WADE MSc FLS 1895-1989}

Arthur Wade died in Rotorua, New Zealand on 20 April 1989. He spent the greater part of his working life in the Department of Botany at the National Museum of Wales in Cardiff, where he made a considerable contribution to the development of the Department, in particular to its growing herbarium and, through his publications, to its increasing prestige. He is especially remembered for the part he played in keeping lichenology alive in Britain at a time when studies in this subject were at a very low ebb. The senior author of this appreciation first met Arthur Wade at his lichen course at the Field Studies Council Centre at Malham Tarn in Yorkshire in 1955 and subsequently at further courses at another of these Centres at Dale Fort in Pembrokeshire; the junior author also first met him at Malham, soon after the British Lichen Society had been formed in 1958 . We both remember with deep gratitude the lucid instruction and generous friendship that he extended to us.

Arthur Wade was born in Leicester on 22 November 1895 and was educated at the Grammar School, and later at the Technical College. His interest in botany began when he was very young, and by the time he was nine he had a collection of pressed plants mounted in scrap-books, and was visiting Leicester Museum regularly to see the botanical exhibits. He compiled a 'Flora of Anstey Lane 'at the age of twelve. At the Museum he was fortunate to come under the influence of A. R. Horwood (1879-1937), the Curator of Botany, who organized an informal group of boys interested in plants, taking them on field excursions and encouraging their study of botany generally. Another member of the group was his school-fellow F. A. Sowter (1899-1972) who became a life-long friend. At school whenever the opportunity arose his essays tended to have a botanical flavour; and he always maintained that Darwin's Voyage of the Beagle had a great influence on him in his boyhood. In 1912 he became an apprentice printing compositor, but in his spare time he still worked with Horwood at the Museum. He became a member of the Botanical Exchange Club in 1915.

In 1917 he married Florence Annie Elizabeth Woods, who predeceased him in 1961. Soon after the marriage he joined the army, and on active service in France in the following year while assisting a stretcher party he received wounds on his right side, in the face and in the elbow. The injury to his right arm meant that after the armistice he did not return to the printing trade as a compositor; it also ended his ambition of ultimately becoming a professional artist. He began again with his left hand however, and not only developed an immaculate handwriting style but also took up sketching again. Throughout his life he produced accomplished landscapes, and his scientific drawings of plants, especially those showing details of structure, were models of accuracy. In 1919 he was still considering a career in printing, and embarked upon a business management training course at Northampton Technical College. At 
this time he compiled a Flora of Aylestone and Newborough Bogs, which was his first publication of lichen records. He also noticed in Nature an advertisement for an appointment at the National Museum of Wales; his application for the post was successful, so he abandoned business management, and on 6 January 1920 commenced work as an Assistant in the Herbarium.

Arthur Wade was involved with all groups of plants. Amongst the flowering plants he was particularly interested in Boraginaceae, and he became an authority on Symphytum and Myosotis; he contributed several notes on these genera to the reports of the Botanical Exchange Club, and became referee for them to the Botanical Society of the British Isles. He was elected a Fellow of the Linnean Society of London in 1925. In 1934 he published, with H. A. Hyde, who was Keeper of Botany at the Museum of Wales from 1922 to 1962 , Welsh Flowering Plants, now in its third edition. His lichen interests brought him the friendship of W. Watson (1872-1960), and together they published a paper on the Lichens of Glamorgan in 1936. Hyde and Wade next published, in 1940, Welsh Ferns. In spite of the title, all British species were included, and it was one of the most useful books on the subject ever written; it still is, in its sixth edition. Quite early in their friendship Wade had communicated his interest in lichens to Sowter, who published a Cryptogamic Flora of Leicestershire in 1950, to which Wade made significant contributions. He followed this up with a paper on Lichens of Pembrokeshire in 1954.

In the late 1950s, as mentioned above, Arthur Wade taught innovative and stimulating lichen courses at Field Studies Council Centres. A number of people later well-known in lichenology benefited greatly from these courses, including K. A. Alvin, D. H. Brown, J. R. Laundon and J. H. Tallis. In conversation with them and with others, such as C. G. Dobbs, F. A. Sowter and T. D. V. Swinscow, he quietly suggested that there was a need for a British society devoted to lichenology. In the event, it was Swinscow who in 1958 called together a meeting of interested people at the British Museum (Natural History) that led to the realization of this idea. Wade was elected secretary of the new society, and served in this capacity from 1958 to 1963 . It was his gentle insistence that gave it the name British Lichen Society, rather than a title involving the word 'lichenological' which was favoured by some of those present at the inaugural meeting. Swinscow took on the editing and production of the Society's journal, The Lichenologist, and Wade contributed a paper on Collema to the first issue, following it up in succeeding years with papers on Alectoria (1959), Anaptychia and Physcia (1960) and Ramalina (1961). The year 1958 was an important one for him, for, in addition to his involvement with the formation of the new society, he published his Lichens of Carmarthenshire, and was awarded an honorary MSc by the University of Wales for his services to botany.

Arthur Wade retired officially in 1961, but continued to visit and work at the Museum until he emigrated to New Zealand twenty years later to live with his daughter. He was elected Honorary Member of the Botanical Society of the British Isles in 1962 and the first Honorary member of the British Lichen Society in 1971, being its President in 1964-65. It is fitting that this eminent botanist should have been commemorated by the conferring of his name on a lichen genus, Wadeana. In 1965 he published in The Lichenologist an important 
paper on Caloplaca, a genus he had been studying in depth for many years. His Flora of Monmouth, which he had been working on since the late 1920 s, was published in 1970. Up until 1981 he continued work on the Flora of Glamorgan, and had written a considerable part of the text. The Flora will be published later in 1989.

Both mentally and physically, Arthur Wade was a very active man, he began every day with a bathe in the sea, or when teaching at Malham, in the tarn. In his final years in Rotorua he travelled quite far afield on painting excursions until infirmity prevented him, and to the end he enjoyed shorter outings in the surrounding countryside. He will never be forgotten by the many who came under his spell: his enthusiasm was an inspiration to all. British lichenologists in particular have good reason to be grateful for his vision and achievement in rekindling a love of the subject, unequalled since the mid-nineteenth century, and the establishment of the world's first and most successful society of lichenology.

\section{F. H. Brightman and M. R. D. Seaward}

[Note: A portrait of Arthur Wade appeared in the issue Lichenologist 8(1): (1976) dedicated to his 80 th birthday -Ed.] 
